\title{
E2F3 wt Allele
}

National Cancer Institute

\section{Source}

National Cancer Institute. E2F3 wt Allele. NCI Thesaurus. Code C96005.

Human E2F3 wild-type allele is located in the vicinity of $6 \mathrm{p} 22$ and is approximately $147 \mathrm{~kb}$ in length. This allele, which encodes transcription factor E2F3 protein, plays a role in both cell cycle progression and transcriptional regulation. 